\title{
SURVEILLANCE FOR VIRAL AND PARASITIC PATHOGENS IN A VULNERABLE AFRICAN LION (PANTHERA LEO) POPULATION IN THE NORTHERN TULI GAME RESERVE, BOTSWANA
}

\author{
Kimberly R. McDermid, ${ }^{1,2,6,7}$ Andrei Snyman, ${ }^{3}$ Frederick J. Verreynne, ${ }^{4}$ John P. Carroll, ${ }^{3}$ Banie \\ L. Penzhorn, ${ }^{5}$ and Michael J. Yabsley ${ }^{1,2,7}$ \\ ${ }^{1}$ Warnell School of Forestry and Natural Resources, 180 E Green Street, University of Georgia, Athens, Georgia 30602, \\ USA \\ 2 Southeastern Cooperative Wildlife Disease Study, Department of Population Health, College of Veterinary Medicine, \\ 589 D. W. Brooks Drive, University of Georgia, Athens, Georgia 30602, USA \\ ${ }^{3}$ School of Natural Resources, University of Nebraska, 3310 Holdrege Street, Lincoln, Nebraska 68583, USA \\ ${ }^{4}$ Veterinary and Agricultural Consultants, PO Box 201028, Gaborone, Botswana \\ ${ }^{5}$ Department of Veterinary Tropical Diseases, Faculty of Veterinary Science, University of Pretoria, Pretoria, South Africa \\ ${ }^{6}$ Current address: San Diego Zoo Safari Park, Harter Veterinary Medical Center, 15500 San Pasqual Valley Road, \\ Escondido, California 92027, USA \\ ${ }^{7}$ Corresponding authors (email: kimberlymcdermid@gmail.com; myabsley@uga.edu)
}

ABSTRACT: African lion (Panthera leo) numbers are decreasing rapidly and populations are becoming smaller and more fragmented. Infectious diseases are one of numerous issues threatening free-ranging lion populations, and low-density populations are particularly at risk. We collected data on the prevalence and diversity of viral and parasitic pathogens in a small lion population in eastern Botswana. During 2012 and 2014, blood samples were collected from 59\% $(n=13)$ of the adult-subadult lions in the Northern Tuli Game Reserve in eastern Botswana. One lion had antibodies to feline panleukopenia virus, two had antibodies to canine distemper virus, and two had feline calicivirus antibodies. Ten of the 13 had antibodies to feline immunodeficiency virus and 11 had feline herpesvirus antibodies. All lions were negative for antibodies to feline coronavirus. Blood samples from all lions were negative for Trypanosoma, Anaplasma, Theileria, and Ehrlichia spp. by molecular testing; however, all lions were positive for Babesia spp. by reverse line blot hybridization assay. Sequencing of amplicons from four lions revealed four groups of Babesia spp. including several genetic variants of Babesia felis, Babesia lengau, and Babesia canis and a group of novel Babesia sequences which were only $96 \%$ similar to other Babesia spp. Six lions were infested with four species of ticks (Rhipicentor nuttalli, Rhipicephalus simus, Rhipicephalus sulcatus, and Rhipicephalus appendiculatus). These data provide the first health assessment of this population and can be used to identify management and conservation strategies to decrease the impact of pathogens on this population. This is particularly important as there is an initiative to incorporate this population into a larger metapopulation of lions from adjacent South Africa and Zimbabwe.

Key words: African lion, Babesia spp., Botswana, DNA sequencing, Panthera leo, pathogen, reverse line blot hybridization assay, serology.

\section{INTRODUCTION}

Management of infectious diseases is an important component to large carnivore conservation, considering that most carnivore species are already threatened due to habitat fragmentation and loss, diminished genetic diversity, overexploitation of carnivores themselves or their prey species, and persecution by humans (Frank et al. 2006). Many wild carnivore species are susceptible to lethal or debilitating pathogens, and coinfections can exacerbate clinical disease (Cleaveland et al. 2007; Munson et al. 2008). For example, concurrent Babesia and canine distemper virus infections were associated with an estimated $35 \%$ reduction $(\sim 1,000$ individuals $)$ in lions during two outbreaks in the Serengeti ecosystem (Roelke-Parker et al. 1996; Munson et al. 2008). The combination of infectious diseases and suboptimal environmental conditions such as loss of habitat, overexploitation and environmental pollution increases the risk of local extinctions (Smith et al. 2009). In addition, increased contact with domestic animals and livestock can result in spillover of significant pathogens including rabies virus 


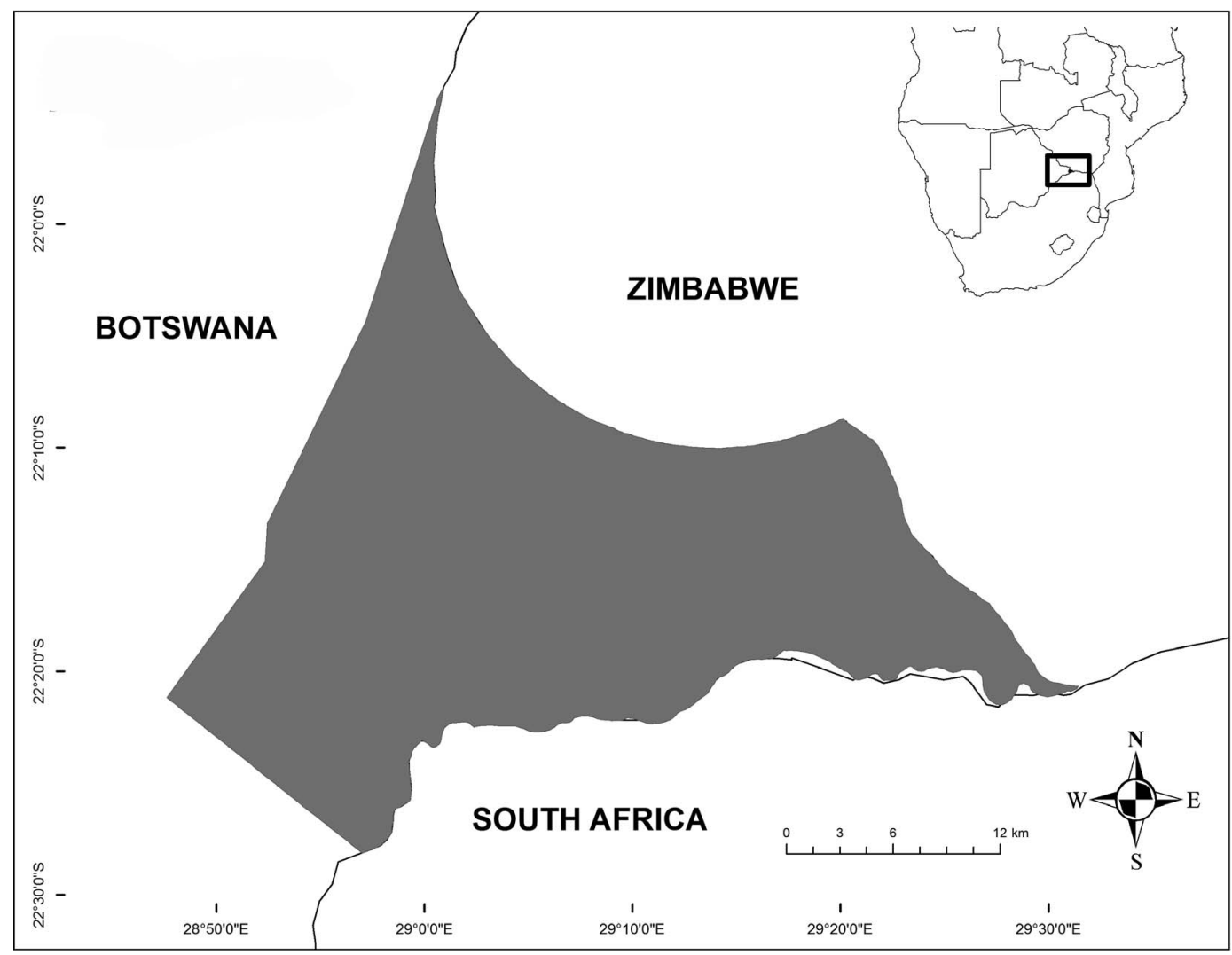

Figure 1. Location of the Northern Tuli Game Reserve (shaded) in eastern Botswana.

in Ethiopian wolves (Canis simensis) and canine distemper virus in lions (e.g., SilleroZubiri et al. 1996; Cleaveland et al. 2007; Smith et al. 2009).

The current population of $\sim 32,000$ lions is rapidly declining and the majority of extant populations are small and isolated (International Union for Conservation of Nature 2014). Of the approximately 67 areas in Africa where resident lion populations are known, 26 $(39 \%)$ contain fewer than 50 individuals (Riggio et al. 2013). Given the rapid decline in lion numbers, protecting extant populations is critical, and it is important from a conservation standpoint to evaluate how infectious diseases may contribute to declining lion numbers and increased risk of local extinction.

We conducted a serologic and molecular survey for pathogens, especially those of potential conservation concern, in a lion population from the Northern Tuli Game
Reserve (NTGR) in eastern Botswana. The NTGR lion population is currently experiencing some immigration and emigration with adjacent areas of South Africa and Zimbabwe. The future development of a $4,870 \mathrm{~km}^{2}$ Greater Mapungubwe Transfrontier Conservation Area with lands from Botswana, South Africa, and Zimbabwe should result in a larger metapopulation of lions.

\section{METHODS}

\section{Study area}

The privately owned NTGR spans $720 \mathrm{~km}^{2}$ of farms and commercial wildlife lodges between Zimbabwe and South Africa (Fig. 1). A diverse range of wildlife is present and a greater number of large predators could be supported due to ample space, water, and prey species; however, surrounding human habitations have led to human-carnivore conflict, persecution, and a 
previous dramatic population decline (Snyman et al. 2014).

\section{Sample collection}

Lions were located by wildlife officers' reports, global positioning system satellite locations, or radio telemetry of tagged animals, baiting and calling stations, and by tracking spoor. Samples were collected during winter (June-August) from 13 lions (Table 1), which represents $59 \%$ of the 22 adult-subadult lions known to be present in NTGR in 2014. Samples originated from two of the four prides, a coalition of two brothers, and the one lone male in NTGR (Snyman et al. 2014). Lions were immobilized by dart injection of 0.03$0.05 \mathrm{mg} / \mathrm{kg}$ medetomidine $20 \mathrm{mg} / \mathrm{mL}$ (Kyron Laboratories, Johannesburg, South Africa) and $0.5-1.0 \mathrm{mg} / \mathrm{kg}$ Zoletil $100 \mathrm{mg} / \mathrm{mL}$ (tiletaminezolazepam; Virbac, Centurion, South Africa) and reversed with $0.2 \mathrm{mg} / \mathrm{kg}$ atipamezole $5 \mathrm{mg} / \mathrm{mL}$ (Pfizer, Sandton, South Africa) administered intramuscularly. Once anesthetized, each lion was given a complete physical examination. Blood samples were collected by femoral or cephalic venipuncture and placed into ethylenediaminetetraacetic acid and serum separator tubes (Greiner Bio-one, Monroe, North Carolina, USA). Clotted blood was centrifuged at 1,250 $\times$ $\mathrm{G}$ for $15 \mathrm{~min}$ and serum was removed and frozen at $-20 \mathrm{C}$ until testing. Whole blood was also frozen until testing. The ears and inguinal region were examined for ectoparasites, and representative samples were preserved in $100 \%$ ethanol.

\section{Serologic and microbiologic diagnostic testing}

Serum samples were tested for antibodies to canine distemper virus (CDV), feline coronavirus $(\mathrm{FCoV})$, feline calicivirus (FCV), feline herpesvirus (FHV), feline panleukopenia virus (FPV), and feline immunodeficiency virus (FIV-Ple) using indirect fluorescent antibody tests $(\mathrm{CDV}, \mathrm{FCoV}$, FCV, FHV, and FPV) and enzyme-linked immunosorbent assay (wild felid FIV strain) as described by Alexander et al. (2010).

We extracted DNA from whole blood (QIAamp DNA mini kit, Qiagen, Whitehead Scientific, South Africa) and tested for Anaplasma-Ehrlichia and Babesia-Theileria by amplification of the $16 \mathrm{~S}$ and 18S rRNA genes, respectively, and reverse line blot hybridization (RLBH) assay with genuswide and species-specific probes (Adamu et al. 2014). For two lions positive with only the Babesia genus-wide probe, near full-length $18 \mathrm{~S}$ rRNA gene was amplified, gel purified, and sequenced by Inqaba Biotec (Pretoria, South Africa) as described by Adamu et al. (2014). For two additional lions that were positive with more than one species-specific probe, the $18 \mathrm{~S}$ rRNA gene was amplified and purified DNA was ligated into the pGEM-T Easy Vector and transformed into JM109 High Efficiency Competent cells (Promega, Madison, Wisconsin, USA). Seven clones were sequenced from each lion. Sequences were analyzed and assembled in Geneious R7 (Biomatters Ltd., Auckland, New Zealand), aligned with related sequences from GenBank (Fig. 1) using the multisequence alignment tool in MEGAv3.1 (Tamura et al. 2011), and phylogenetic analysis conducted using the maximum likelihood algorithm and JC69 model (http://www. phylogeny.fr/). Nested polymerase chain reaction for Trypanosoma was conducted as described by Delespaux et al. (2003).

\section{Statistical analyses}

Potential differences in prevalence between age classes and sex were tested using Fisher's exact test.

All methods were approved by the Institutional Animal Care and Use Committee at University of Georgia (A2014 01-010) and by the Ministry of Environment, Wildlife and Tourism in Botswana (EWT 8/36/4 XXIV).

\section{RESULTS}

Antibodies to each of the viral pathogens except $\mathrm{FCoV}$ were detected in at least one lion (Table 1). No significant differences were detected based on age or sex $(P>0.05)$. All 13 lions were positive for Babesia genus-wide probes but only two lions (lions 2 and 3) were positive for species-specific probes (Table 1). All lions were negative for Trypanosoma and genus-wide probes for Anaplasma, Ehrlichia, and Theileria. Four tick species were found on six lions (Table 1).

The most-common sequences from lions 2 and 3 were most similar to Babesia felis (four unique sequences, 1,585-1,587 base pairs [bp]) and Babesia lengau (three unique sequences, 1,593 bp) (Table 1 and Fig. 2). Three additional unique sequences were also obtained from these two lions; one sequence from lion 2 was $95.5-96 \%$ similar to two unique sequences $(99.1 \%$ similar to each other) obtained from lion 3. Phylogenetically, these three sequences were present in an ancestral position within the large archaeopiroplasmid clade (Fig. 2). Amplicons from two lions that were only positive with the genus- 


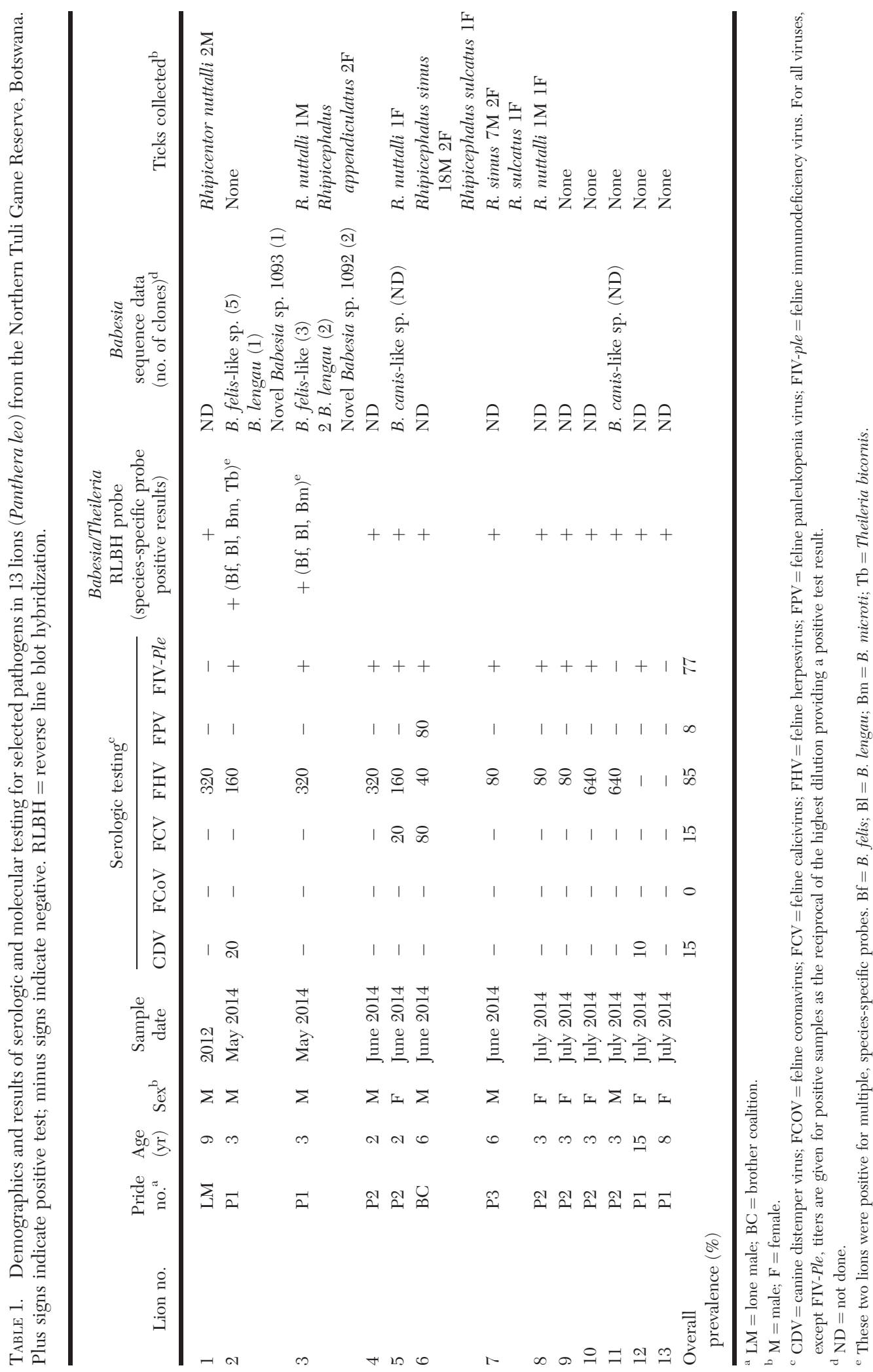




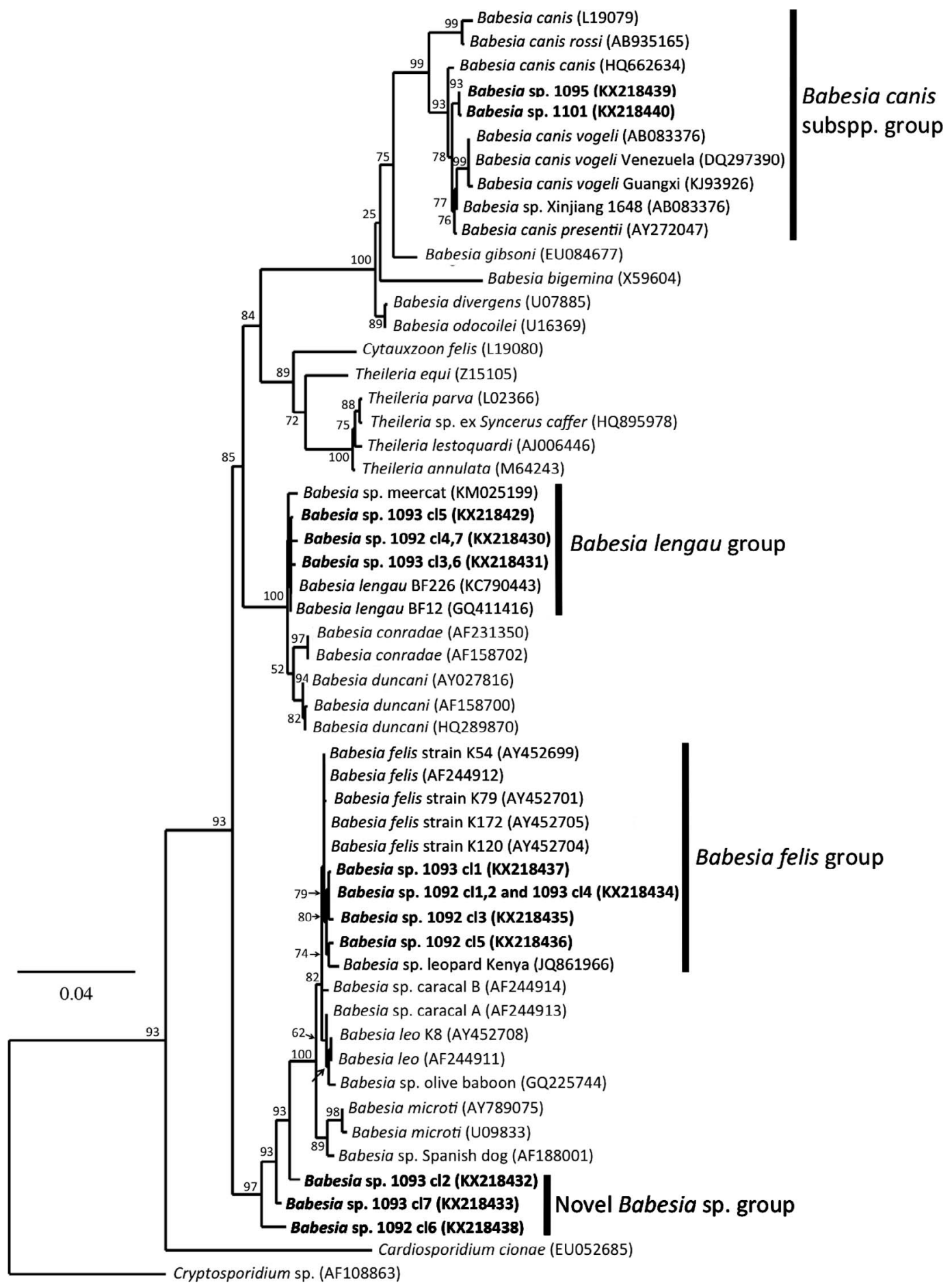

Figure 2. Phylogenetic tree showing relationships of the various Babesia spp. detected in lions (Panthera leo) from Northern Tuli Game Reserve, Botswana. The four clades of Babesia spp. detected are marked and new sequences from this study are bolded. GenBank accession numbers are shown in parentheses. 
wide probes were sequenced and sequences were $99.9 \%$ similar $(1,510 / 1,511 \mathrm{bp})$ to each other and were most similar $(98.1 \%)$ to Babesia sp. Xinjiang (AB083376). Phylogenetically, these sequences formed a distinct group within a larger group Babesia canis subspecies (Fig. 2).

\section{DISCUSSION}

A few researchers have investigated the exposure of lions to various pathogens in Botswana; however, these studies were conducted in central or northern populations (Osofsky et al. 1996; Ramsauer et al. 2007; Alexander et al. 2010). We found that lions in southeastern Botswana were exposed to several pathogens, and prevalences were similar to lion populations in central or northern Botswana. Our data indicate that CDV is circulating among lions at NTGR, and we detected several Babesia spp. including one or more novel species.

Canine distemper virus is one of the most important pathogens of carnivores worldwide. Serologic studies indicate that the exposure of lions to CDV varies by population, and outbreaks of clinical disease are generally associated with periods of stress, concurrent infections with Babesia spp., or other unknown factors (Munson et al. 2008; Alexander et al. 2010). The prevalences of antibodies to CDV in some central and northern Botswana lion populations were higher compared to the prevalence we detected at NTGR. A longitudinal study at NTGR is needed to understand the long-term CDV transmission at NTGR because lethal and "silent" CDV epidemics and periods of very low prevalence have been reported in other lion populations (Munson et al. 2008). The host range of CDV is wide and it can be maintained in wild systems through interspecies transmission among wild and domestic carnivores. It is unknown if CDV exposure of lions in the NTGR is occurring from sympatric wild carnivores or domestic dogs, but future studies should investigate prevalence and genetic types present in carnivores in Botswana.
Lions are hosts for at least four Babesia species (B. felis, B. leo, B. lengau, and B. gibsoni; Munson et al. 2008; Williams et al. 2014). Coinfection with multiple Babesia spp. has been reported and two of our lions were coinfected with at least three species (Bosman et al. 2007; Munson et al. 2008). In a longitudinal study in Tanzania, coinfections were randomly detected, suggesting either frequent reinfections or cyclic parasitemias (Munson et al. 2008). In addition, we detected sequence heterogenetity in the $18 \mathrm{~S}$ rRNA gene of B. felis and B. lengau from the NTGR lions, which could have important implications for RLBH assays (Bhoora et al. 2009). Before our study, only one B. canis subspecies (Babesia canis presentii) had been reported from a domestic cat; however, this is the first report from a wild felid. Interestingly, we also identified three novel sequences related to the archaeopiroplasmids that likely represent novel species. The four tick species collected from the NTGR lions have been previously reported on lions in other regions of Africa (e.g., Horak et al. 2010). Information on tick species and Babesia spp. prevalence and diversity from various lion populations is important because no vectors have been identified for any of the Babesia species detected in lions, and Babesia can be pathogenic under certain circumstances (Munson et al. 2008).

Similar to previous findings, antibodies to FCoV, FCV, and FPV were rare or absent. No FCoV antibodies were detected in lions from Makgadikgadi National Park and Khutse and Central Kalahari Wildlife Reserves in central Botswana while only a low prevalence was noted in three populations in northern and western Botswana (Ramsauer et al. 2007; Alexander et al. 2010). Similarly, the only two lion populations in Botswana with antibodies to FPV were the two northernmost (Ramsauer et al. 2007; Alexander et al. 2010). Lion populations positive for antibodies to FCV were more widespread but prevalence was generally low (Ramsauer et al. 2007; Alexander et al. 2010). Although these viruses have not been associated with outbreaks, cub survival during an FCV outbreak in the 
Serengeti was lower than in nonepidemic years (Packer et al. 1999).

The high prevalence of antibodies to FIVPle and FHV was consistent with most studies on lions from southern and eastern Africa, including one study in central Botswana (Hofmann-Lehmann et al. 1996; Packer et al. 1999; Driciru et al. 2006; Ramsauer et al. 2007; Roelke et al. 2009). Feline herpesvirus has not been associated with clinical disease in free-ranging lions but has been associated with mortality of a captive lion (see Driciru et al. 2006). Historically, FIV-Ple has not been considered a cause of clinical disease in lions; however, recent research suggests FIV-Ple could be contributing to a loss of immune competence, and some subtypes of FIV-Ple are possibly more pathogenic than others (Pecon-Slattery et al. 2008; Roelke et al. 2009; Troyer et al. 2011; O'Brien et al. 2012). Further, during the 1994 Serengeti CDV outbreak, lions infected with FIV-Ple subtype B were twice as likely to survive compared to lions infected with subtypes A or C (Troyer et al. 2011). Future studies should investigate the strain of FIV-Ple found in freeranging lions, and other felids, and the possible impacts these strains have on their health.

In conclusion, lions at NTGR were exposed to several pathogens including some that are known to be pathogenic in lions (e.g., CDV and Babesia); however, all were in good physical condition. Most of these pathogens generally cause asymptomatic infections, but clinical disease may be triggered by numerous factors such as stress, loss or degradation of habitat, human persecution and overexploitation, or changes in interactions with sympatric wild or domestic carnivores that may alter transmission dynamics. There are plans to incorporate the NTGR lion population into the Greater Mapungubwe Transfrontier Conservation Area, creating a larger metapopulation; however, this area is concurrently undergoing a rapid human population increase which could pose a higher risk for lions due to conflicts and exposure to domestic animal pathogens. Efforts should be made to minimize interactions of free-ranging lions with domestic dogs and livestock so as to minimize potential pathogen spillover. Possibilities include creation of buffer zones between wildlife and domestic animal areas, vaccination campaigns for domestic canines, felines, and livestock, and domestic dog population control (Cleveland et al. 2007; Smith et al. 2009).

\section{ACKNOWLEDGMENTS}

Funding was provided by the Oklahoma City Zoo Conservation Action Now Grants Program, Idea Wild, EcoTraining Inc., Mashatu Game Reserve and Tuli Wilderness Safaris, Warnell School of Forestry and Natural Resources-UGA, and the School of Natural Resources-University of Nebraska. The authors thank the Office of the President, the Ministry of Environment, Wildlife and Tourism, and the Department of Wildlife and National Parks, Botswana for permission and the NTGR landowners and David Evans, Pete le Roux, and Stuart Quinn for assistance. We thank H. Heyne (Onderstepoort Veterinary Institute) for tick identification and M. van Vuuren, J. Greyling, M. Troskie, and I. Vorster (University of Pretoria) for laboratory testing.

\section{LITERATURE CITED}

Adamu M, Troskie M, Oshadu DO, Malatji DP, Penzhorn BL, Matjila PT. 2014. Occurrence of tick-transmitted pathogens in dogs in Jos, Plateau State, Nigeria. Parasit Vectors 7:119.

Alexander KA, McNutt JW, Briggs MB, Standers PE, Funston P, Hemson G, Keet D, van Vuuren M. 2010. Multi-host pathogens and carnivore management in southern Africa. Comp Immunol Microbiol Infect Dis 33:249-265.

Bhoora R, Franssen L, Oosthuizen MC, Guthrie AJ, Zweygarth E, Penzhorn BL, Jongejan F, Collins NE. 2009. Sequence heterogeneity in the $18 \mathrm{~S}$ rRNA gene within Theileria equi and Babesia caballi from horses in South Africa. Vet Parasitol 159:112-120.

Bosman AM, Venter EH, Penzhorn BL. 2007. Occurrence of Babesia felis and Babesia leo in various wild felid species and domestic cats in Southern Africa, based on reverse line blot analysis. Vet Parasitol 144: 33-38.

Cleaveland S, Mlengeya T, Kaare M, Haydon D, Lembo T, Laurenson MK, Packer C. 2007. The conservation relevance of epidemiological research into carnivore viral diseases in the Serengeti. Conserv Biol 21:612622 .

Delespaux V, Ayral F, Geysen D, Geerts S. 2003. PCRRFLP using SSU-rDNA amplification: Applicability for the diagnosis of mixed infections with different 
trypanosome species in cattle. Vet Parasitol 117:185193.

Driciru M, Siefert L, Prager KC, Dubovi E, Sande R, Princee F, Munson L. 2006. A serosurvey of viral infections in lions (Panthera leo) from Queen Elizabeth National Park, Uganda. J Wildl Dis 42: 667-671.

Frank L, Hemson G, Kushnir H, Packer C. 2006. Lions, conflict and conservation in Eastern and Southern Africa. In: The eastern and southern African lion conservation workshop, Johannesburg, South Africa, 11-13 January, $16 \mathrm{pp}$.

Hofmann-Lehmann R, Fehr D, Grob M, Elgizoli M, Packer C, Martenson JS, Lutz H. 1996. Prevalence of antibodies to feline parvovirus, calicivirus, herpesvirus, coronavirus, and immunodeficiency virus and of feline leukemia virus antigen and the interrelationship of these viral infections in freeranging lions in east Africa. Clin Diagn Lab Immunol 3:554-562.

Horak IG, Heyne H, Donkin EF. 2010. Parasites of domestic and wild animals in South Africa: XLVIII. Ticks (Acari: Ixodidae) infesting domestic cats and wild felids in southern Africa. Onderstepoort J Vet Res 77:1-7.

International Union for Conservation of Nature (IUCN). 2014. IUCN red list of threatened species. Version 2014.3. http://www.iucnredlist.org. Accessed January 2015.

Munson L, Terio KA, Kock R, Mlengeya T, Roelke ME, Dubovi E, Packer C. 2008. Climate extremes promote fatal co-infections during canine distemper epidemics in African lions. PLoS One 3:e2545.

O’Brien SJ, Troyer JL, Brown MA, Johnson WE, Antunes A, Roelke ME, Pecon-Slattery J. 2012. Emerging viruses in the Felidae: Shifting paradigms. Viruses 4: 236-257.

Osofsky SA, Hirsch KJ, Zuckerman EE, Hardy WD Jr. 1996. Feline lentivirus and feline oncovirus status of free-ranging lions (Panthera leo), leopards (Panthera pardus), and cheetahs (Acinonyx jubatus) in Botswana: A regional perspective. J Zoo Wildl Med 27: 453-467.

Packer C, Altizer S, Appel M, Brown E, Martenson J, O'Brien SJ, Lutz H. 1999. Viruses of the Serengeti: Patterns of infection and mortality in African lions. $J$ Anim Ecol 68:1161-1178.

Pecon-Slattery J, McCracken CL, Troyer JL, VandeWoude S, Roelke M, Sondgeroth K, Winterbach C, Winterbach H, O’Brien SJ. 2008. Genomic organiza- tion, sequence divergence, and recombination of feline immunodeficiency virus from lions in the wild. BMC Genomics 9:66.

Ramsauer S, Bay G, Meli M, Hofmann-Lehmann R, Lutz H. 2007. Seroprevalence of selected infectious agents in a free-ranging, low-density lion population in the Central Kalahari Game Reserves in Botswana. Clin Vaccine Immunol 14:808-810.

Riggio J, Jacobson A, Dollar L, Bauer H, Becker M, Dickman A, Pimm S. 2013. The size of savannah Africa: A lion's (Panthera leo) view. Biodivers Conserv 22:17-35.

Roelke ME, Brown MA, Troyer JL, Winterbach H, Winterbach C, Hemson G, O’Brien SJ. 2009. Pathological manifestations of feline immunodeficiency virus (FIV) infection in wild African lions. Virology 390:1-12.

Roelke-Parker ME, Munson L, Packer C, Kock R, Cleaveland S, Carpenter M, Appel MJ. 1996. A canine distemper virus epidemic in Serengeti lions (Panthera leo). Nature 379:441-445.

Sillero-Zubiri C, King AA, Macdonald DW. 1996. Rabies and mortality in Ethiopian wolves (Canis simensis). J Wildl Dis 32:80-86.

Smith KF, Acevedo-Whitehouse K, Pedersen AB. 2009. The role of infectious diseases in biological conservation. Anim Conserv 12:1-12.

Snyman A, Jackson CR, Funston PJ. 2014. The effect of alternative forms of hunting on the social organization of two small populations of lions Panthera leo in southern Africa. Oryx 49:604-610.

Tamura K, Peterson D, Peterson N, Stecher G, Nei M, Kumar S. 2011. MEGA5: Molecular evolutionary genetics analysis using maximum likelihood, evolutionary distance, and maximum parsimony methods. Mol Biol Evol 28:2731-2739.

Troyer JL, Roelke ME, Jespersen JM, Baggett N, Buckley-Beason V, MacNulty D, O'Brien SJ. 2011. FIV diversity: FIVPle subtype composition may influence disease outcome in African lions. Vet Immunol Immunopathol 143:338-346.

Williams BM, Berentsen A, Shock BC, Teixiera M, Dunbar MR, Becker MS, Yabsley MJ. 2014. Prevalence and diversity of Babesia, Hepatozoon, Ehrlich$i a$, and Bartonella in wild and domestic carnivores from Zambia, Africa. Parasitol Res 113:911-918.

Submitted for publication 19 September 2015. Accepted 13 May 2016. 